\title{
Pengaruh Penambahan Jamur Tiram (PLEUROTUS SP.) Terhadap Nilai Komposisi Kimia Dan Organoleptik Bakso Ayam Broiler
}

\section{Effect of Addition Oyster Mushrooms (Pleurotus sp.) on Chemical Composition and Organoleptic Value of Broiler Meatballs}

\author{
Ria Harmayani ${ }^{1 *}$ dan Nefi Andriana Fajri ${ }^{2}$ \\ 1,2 Fakultas Peternakan, Universitas Nahdlatul Wathan Mataram \\ Jl. Kaktus No. 1-3 Mataram, 83126, NTB, Indonesia. \\ *corresponding author, email: riaharmayani@gmail.com
}

Manuscript received: 27-10-2020. Accepted: 23-05-2021

\begin{abstract}
ABSTRAK
Penelitian eksperimental yang bertujuan untuk mengetahui pengaruh penambahan jamur tiram terhadap nilai komposisi kimia dan organoleptik bakso ayam broiler. Penelitian dilakukan selama 4 bulan dari bulan Juli hingga Oktober 2020. Pembuatan bakso ayam broiler dan uji organoleptik dilakukan di Laboratorium Fakultas Peternakan UNW Mataram dan analisa komposisi kimia dilakukan di Laboratorium INMT Universitas Mataram. Rancangan penelitian yang digunakan adalah Rancangan Acak Lengkap dengan 4 perlakuan yaitu penambahan jamur tiram sebanyak 0\%, 10\%, $20 \%$ dan 30\% dari berat daging ayam dan setiap perlakuan terdapat 5 ulangan. Data hasil penelitian komposisi kimia bakso ayam dianalisa menggunakan Analisa Varian dan dilanjutkan dengan uji BNT dan nilai organoleptik diperoleh dengan menggunakan hedonic scale dari 30 panelis yang agak terlatih sebagai ulangan, lalu dianalisa menggunakan Friedman Test. Hasil analisa varian menunjukkan bahwa penambahan jamur tiram dalam adonan bakso ayam broiler memberikan pengaruh sangat nyata $(\mathrm{P}>0,01)$ terhadap nilai komposisi kimia yaitu kadar air, abu, lemak, serat dan protein dan berpengaruh nyata $(\mathrm{P}>0,05)$ terhadap nilai organoleptik yaitu kesukaan warna, rasa dan daya terima bakso, tetapi tidak berpengaruh nyata $(\mathrm{P}<0,05)$ terhadap kesukaan aroma dan tekstur bakso. Formulasi penambahan jamur tiram pada bakso ayam broiler berdasarkan nilai komposisi kimia terdapat pada penambahan jamur tiram $10 \%$ mengandung protein tertinggi sebesar $8,51 \pm 0,014 \%$, jika dibandingkan penambahan jamur tiram $0 \%, 20 \%$ dan $30 \%$ dan telah memenuhi SNI bakso daging kombinasi dan dapat direkomendasikan menjadi terapi gizi di tengah masa pandemi Covid-19. Berdasarkan nilai organoleptik, formulasi bakso ayam broiler dengan penambahan jamur tiram sebanyak $30 \%$ dapat memberikan nilai organoleptik (warna, rasa dan daya terima) lebih tinggi jika dibandingkan dengan penambahan jamur tiram 0\%, $10 \%$ dan $20 \%$.
\end{abstract}

Kata kunci: bakso; jamur; komposisi; organoleptik. 


\begin{abstract}
Experimental research aimed to determine the effect of the addition of oyster mushrooms on the chemical composition and organoleptic value of broiler chicken meatballs. The research was corried out for 4 months from July to October 2020. The making of broiler chicken meatballs and organoleptics tests was carried out at the Laboratory of the Faculty of Animal Science UNW Mataram and chemical composition analysis was carried out at the INMT Laboratory of Mataram University. The research design used was a completely randomized design with 4 treatments, namely the addition of oyster mushrooms as much as $0 \%, 10 \%, 20 \%$ and $30 \%$ of the weight of chicken meat and each treatment there were 5 replications. The data from the research on the chemical composition of chicken meatballs were analyzed using variant analysis and continued with the LSD test and the organoleptic values were obtained using a hedonic scale from 30 panelists who were somewhat trained as replication, then analyzed using the Friedman Test. The analysis of variance result showed that the addition of oyster mushrooms in broiler's chicken meatball dough had a very significant effect $(\mathrm{P}>0.01)$ on the value of chemical composition, namely moisture, ash, fat, fiber and protein content and had a significant effect $(\mathrm{P}>0.05)$ organoleptic values are colour preference, taste and aceeptance of meatballs, but it has no significant effect $(\mathrm{P}<0.05)$ on the preference for aroma and texture of meatballs. The formulation of addition oyster mushrooms to broiler chicken meatballs based on the chemical composition value is the addition of $10 \%$ oyster mushrooms containing the highest protein of $8.51 \pm 0.014 \%$, when compared to the addition of mushroom addition $0 \%, 20 \%$ and $30 \%$ and has met Indonesian National Standard for combination meatball and can be recomended for as nutritional terapy in the midst of the Covid-19 pandemic. Based on the organoleptic value, the formulation of broiler chicken meatballs with the addition of oyster mushrooms as much as $30 \%$ can provide higher organoleptic (colour, taste and acceptability) when compared to the addition of $0 \%$, $10 \%$ and $20 \%$.
\end{abstract}

Key words: composition; organoleptic; meatballs; mushrooms.

\title{
PENDAHULUAN
}

Pandemi Covid-19 di Indonesia menuntut new normal dan peningkatan kesadaran masyarakat untuk menjaga kesehatan yang dimulai dengan usaha meningkatkan imunitas yaitu dengan mengonsumsi pangan yang aman dan sehat serta rasa yang enak. Bakso merupakan salah satu pangan hasil olahan daging yang sangat popular dan menjadi viral dengan kreasi bakso corona di Surabaya. Selain bergizi, bakso mudah dibuat dengan beragam bahan baku. Bahan utama adonannya umumnya adalah daging yang dilumatkan, dicampur dengan bahan lainnya dan dibentuk bulatan, selanjutnya direbus dengan bahan baku berupa daging, binder (bahan pengikat), filler (bahan pengisi) dan bahan tambahan lain. Binder dan filler umumnya adalah tepung tapioka, sedangkan bahan tambahan lain adalah garam, bawang putih, dan bahan penyedap, dimana daging yang biasa digunakan sebagai bahan utama adalah daging ayam broiler yang kaya protein (Purnomo, 2005).

Permintaan bakso meningkat karena bervariasi dan dapat dibuat dengan penambahan jamur, yaitu jamur tiram yang merupakan salah satu alternatif sumber pangan fungsional dan dapat diolah dengan campuran daging sebagai upaya peningkatan gizi nasional melalui peningkatan kecukupan dan keamanan pangan bergizi dan memiliki prospek yang cerah secara ekonomis di masa depan (Tjokrokusumo, 2008). Kandungan asam amino esensial jamur tiram 46,0 gram per 100 gram, mendekati kandungan asam amino telur ayam 47,1 gram per 100 gram (Thomy, 2004). Kandungan chitin pada serat jamur tiram, memperbaiki kinerja metabolisme pencernaan, sedangkan lemak yang rendah mampu mengurangi 
kolesterol darah, mencegah penyakit jantung koroner, sehingga sangat cocok untuk dikonsumsi sebagai diet sehat. Protein jamur tiram rata-rata 3,5-4\% dari berat basah, sedangkan berdasarkan berat kering, mengandung 19-35\% protein, 72\% lemak tidak jenuh dan $28 \%$ asam lemak jenuh. Kandungan asam folatnya yang tinggi, dapat menyembuhkan anemia dan anti tumor, serta mampu mencegah dan menanggulangi kekurangan gizi dan kekurangan zat besi (Sumarmi, 2006).

Kebutuhan konsumsi jamur terus meningkat sebanding dengan pertumbuhan jumlah penduduk dan pendapatan, serta perubahan pola konsumsi makanan terlebih saat pandemi Covid 19 sehingga mengonsumsi jamur tiram memiliki keuntungan untuk kesehatan. Tingkat konsumsi jamur nasional menurut (BPS, 2018), per tahun mencapai 18 gram per kapita, masih jauh dari Jepang dan Singapura yang mencapai $1 \mathrm{~kg}$ per kapita. Berdasarkan Susenas menurut Setjen Pertanian RI (2015), rata-rata konsumsi jamur nasional dalam setahun selama kurun waktu 2011-2013 sebanyak 57 gram/kapita/tahun, tahun 2014 meningkat menjadi 87 gram/kapita/tahun dan tahun 2017 meningkat menjadi 117gram/kapita/tahun (BPS, 2018).

Pemanfaatan jamur tiram sebagai bahan campuran adonan bakso dapat menambah keragaman cita rasanya. Bakso ayam yang mengandung sebagian besar komponen hewani, perlu ditingkatkan kualitasnya dengan penambahan komponen nabati berupa jamur tiram. Penambahan jamur tiram pada aras $15 \%$ dari berat adonan bakso ayam petelur afkir dapat meningkatkan kualitas kimia dan organoleptiknya, kandungan kadar air dan protein pada bakso ayam broiler dengan putih telur dengan bahan pengenyal yang berbeda telah memenuhi SNI (Munassir, dkk, 2018), namun masih diperlukan data mengenai pengaruh penambahan jamur tiram terhadap nilai komposisi kimia dan organoleptik dan level terbaik penambahan jamur tiram pada bakso ayam broiler, sehingga diperlukan penelitian ini agar menghasilkan bakso dengan komposisi kimia yang tinggi dan mampu meningkatkan daya terima konsumen, sehingga menghasilkan formulasi bakso sehat yang berkualitas di masa pandemi.

\section{Lokasi dan Waktu Penelitian}

\section{BAHAN DAN METODE}

Penelitian ini merupakan penelitian eksperimental yang dilakukan di Laboratorium Teknologi Pengolahan Hasil Ternak (TPHT) Fakultas Peternakan Universitas Nahdlatul Wathan Mataram dan analisa proksimat dilaksanakan di Laboratorium Ilmu Nutrisi dan Makanan Ternak (INMT) Fakultas Peternakan Universitas Mataram selama empat bulan dari bulan Juli-Oktober 2020.

\section{Materi Penelitian}

Bahan yang digunakan yaitu bahan utama dan bahan pendukung. Bahan utama adalah daging ayam broiler (boneless dada) dan jamur tiram putih. Bahan pendukung adalah tepung tapioka "rosebrand", bumbu seperti bawang putih, merica dan garam, air dan es batu. Bahan untuk analisa proksimat antara lain $\mathrm{H}_{2} \mathrm{SO}_{4}$ pekat, $\mathrm{K}_{2} \mathrm{SO}_{4}, \mathrm{C}_{\mathrm{USO}}, \mathrm{N}_{\mathrm{a}} \mathrm{OH} 40 \%, \mathrm{H}_{3} \mathrm{BO}_{3} 3 \%$, Batuh didih, $\mathrm{H}_{2} \mathrm{SO}_{4}$ 0,1 N, Aquades, Indikator $\mathrm{BCG}$ dan $\mathrm{MM}$, ether, kloroform, petroleumbenzene, heksana dan aseton, serta seperangkat bahan untuk uji organoleptik. 
Peralatan yang digunakan untuk pembuatan bakso adalah timbangan, alat penggiling daging, kompor, panci, pisau, baskom dan sendok. Peralatan yang digunakan untuk analisis proksimat adalah seperangkat alat untuk analisa proksimat dan seperangkat alat untuk uji organoleptik.

\section{Metode Penelitian}

Metode yang digunakan dalam penelitian ini adalah eksperimental laboratorium, dimana percobaan diatur menurut rancangan acak lengkap (RAL) yang dirancang dengan menggunakan 4 perlakuan yaitu 0\% (K), penambahan jamur tiram 10\% (P1), penambahan jamur tiram 20\% (P2), penambahan jamur tiram 30\% (P3) dari berat daging dan setiap perlakuan terdiri dari 5 ulangan.

\section{Pelaksanaan Percobaan}

Pelaksanaan percobaan terdiri atas tahap persiapan penelitian yaitu persiapan alat dan bahan dan proses pembuatan bakso, sedangkan tahap penelitian yaitu pengujian komposisi kimia dan organoleptik bakso di laboratorium.

\section{Tahap Persiapan Percobaan}

Cara membuat bakso yaitu menghaluskan daging ayam, lalu menggilingnya. Daging yang sudah halus dipindahkan ke mesin pencampur dan mencampurkan tepung tapioka, bumbu-bumbu, es batu dan jamur tiram tanpa ada tambahan bahan pengenyal, pengembang dan pengawet dengan mesin penggiling bakso sampai adonan homogen dan mudah dibentuk. Membentuk bulatan dengan tangan seukuran kelereng (diameter $3 \mathrm{~cm}$ ) dan merebusnya dalam air panas selama 10 menit. Penambahan jamur tiram dalam empat level perlakuan berdasarkan berat daging ayam yaitu 0\% (K), 10\% (P1), 20\% (P2), dan 30\% (P3).

Tabel 1. Komposisi Adonan Bakso Per Unit Percobaan

\begin{tabular}{lcccc}
\hline \multirow{2}{*}{ Bahan-bahan } & \multicolumn{4}{c}{ Komposisi (gram) } \\
\cline { 2 - 5 } & $\begin{array}{c}\text { Kontrol } \\
(\mathbf{K})\end{array}$ & $\begin{array}{c}\text { Perlakuan 1 } \\
(\mathbf{P 1})\end{array}$ & $\begin{array}{c}\text { Perlakuan 2 } \\
(\mathbf{P 2})\end{array}$ & $\begin{array}{c}\text { Perlakuan 3 } \\
(\mathbf{P 3})\end{array}$ \\
\hline Daging Ayam Broiler & 500 & 500 & 500 & 500 \\
$\quad$ Jamur Tiram & - & 50 & 100 & 150 \\
Tepung Tapioka & 250 & 250 & 250 & 250 \\
Bumbu & 20 & 20 & 20 & 20 \\
Es Batu & 30 & 30 & 30 & 30 \\
\hline
\end{tabular}

Tahap Pelaksanaan Percobaan

\section{Pengujian Komposisi Kimia}

Analisa proksimat bakso dilakukan berdasarkan metode analisa bahan makanan berdasarkan FAO (2011) meliputi kadar air, abu, lemak kasar, serat kasar, dan protein kasar.

\section{Pengujian Organoleptik}

Uji organoleptik merupakan uji hedonik bertujuan untuk mengetahui tingkat kesukaan panelis terhadap warna, rasa, aroma, tekstur, dan daya terima bakso. Dengan menggunakan 30 panelis yang agak terlatih sebagai ulangan. Beberapa indikator yang digunakan adalah warna, rasa, aroma, dan tekstur dengan metode hedonic scale (skala hedonik) pada tabel 2. 
Tabel 2. Skor Hedonik Untuk Tingkat Kesukaan Terhadap Warna, Rasa, Aroma dan Tekstur pada Uji Hedonik

\begin{tabular}{ccc}
\hline Skor Hedonik & Skor & Kisaran Nilai \\
\hline Sangat suka & 5 & $4,1-5$ \\
Suka & 4 & $3,1-4$ \\
Cukup Suka & 3 & $2,1-3$ \\
Kurang Suka & 2 & $1,1-2$ \\
Tidak Suka & 1 & $0-1$ \\
\hline
\end{tabular}

\section{Variabel Penelitian}

Variabel yang diamati dalam penelitian ini antara lain:

1. Komposisi kimia meliputi kadar air, abu, lemak kasar, serat kasar, protein kasar bakso ayam broiler

2. Nilai organoleptik meliputi warna, rasa, aroma, tekstur dan daya terima bakso ayam broiler.

\section{Analisis Data}

Data komposisi kimia, dianalisis menggunakan Analisis Varian pada tingkat kepercayaan $5 \%$ dan $1 \%$, jika berbeda nyata dilanjutkan dengan uji BNT. Data yang diperoleh dari nilai organoleptik dihitung menggunakan statistik nonparametrik yaitu Friedman Test. Panelis diasumsikan tidak seragam, sehingga dijadikan sebagai kelompok (Suradi, 2007).

\section{HASIL DAN PEMBAHASAN}

\section{Komposisi Kimia Bakso Ayam Broiler Dengan Penambahan Jamur Tiram}

Kualitas bakso dipengaruhi oleh komposisi bahan penyusunnya. Hasil bakso yang berkualitas harus menggunakan bahan penyusun yang tepat dan daging yang digunakan harus baik dan segar. Bakso sebagai produk olahan daging mempunyai kandungan nilai gizi yang tinggi karena kaya protein hewani yang sangat diperlukan oleh manusia, terutama pada masa pertumbuhan. Bakso mengandung protein, lemak, dan vitamin yang diperlukan oleh tubuh. Hasil analisa proksimat bakso ayam dengan penambahan jamur tiram terdapat pada tabel 3 .

Tabel 3. Rataan Nilai Komposisi Kimia Bakso Ayam Dengan Penambahan Jamur Tiram

\begin{tabular}{cccccc}
\hline Parameter Nilai & \multicolumn{3}{c}{ Persentase Penambahan Jamur Tiram } & P \\
\cline { 2 - 5 } Gizi (\%) & K (kontrol) & P1 (10\%) & P2 $20 \%)$ & P3 (30\%) & \\
\hline Kadar Air & $70 \%)$ & & & & \\
Kadar Abu & $1,21 \pm 0,22^{\mathbf{a}}$ & $71,31 \pm 0,07^{\mathbf{b}}$ & $72,49 \pm 0,03^{\mathbf{c}}$ & $72,63 \pm 0,0005^{\mathbf{c}}$ & $\mathrm{S}$ \\
Kadar Lemak & $0,50 \pm 0,004^{\mathbf{a}}$ & $0,29 \pm 0,002^{\mathbf{b}}$ & $0,66 \pm 0,01^{\mathbf{c}}$ & $0,85 \pm 0,0094^{\mathbf{d}}$ & $\mathrm{S}$ \\
Kadar Serat & $1,98 \pm 0,009^{\mathbf{a}}$ & $2,53 \pm 0,12^{\mathbf{b}}$ & $0,07 \pm 0,0007^{\mathbf{c}}$ & $0,06 \pm 0,01^{\mathbf{c}}$ & $\mathrm{S}$ \\
Kadar Protein & $5,73 \pm 0,10^{\mathbf{a}}$ & $8,52 \pm 0,014^{\mathbf{b}}$ & $7,69 \pm 0,003^{\mathbf{a}}$ & $1,72 \pm 0,003^{\mathbf{a}}$ & $\mathrm{S}$ \\
\hline
\end{tabular}

Sumber: Data Primer Diolah (2020).

Keterangan: S: signifikan

Superskrip yang berbeda pada baris yang sama menunjukkan perbedaan yang nyata $(\mathrm{P}<0,05)$. 
Tabel 3 menunjukkan bahwa komposisi kimia bakso ayam broiler dengan penambahan jamur tiram bervariasi, baik kadar air, abu, lemak, serat dan proteinnya. Kadar

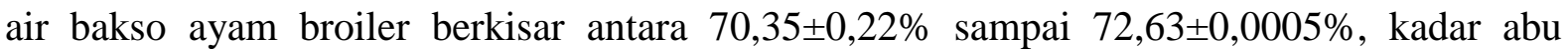
berkisar antara $0,29 \pm 0,002 \%$ sampai $1,21 \pm 0,01 \%$, kadar lemak berkisar antara $0,06 \pm 0,01 \%$ sampai $0,50 \pm 0,004 \%$, kadar serat berkisar antara $1,72 \pm 0,003 \%$ sampai $2,53 \pm 0,12 \%$ dan kadar protein berkisar antara 5,73 $\pm 0,10 \%$ sampai $8,52 \pm 0,014 \%$. Hasil analisa varian menunjukkan bahwa persentase penambahan jamur tiram berpengaruh sangat nyata $(\mathrm{P}<0,01)$ terhadap kadar air, abu, lemak, serat dan protein bakso. Setelah dilakukan uji lanjut kadar air, terdapat perbedaan nyata $(\mathrm{P}<0,05)$ antar perlakuan, kecuali tidak berbeda nyata $(\mathrm{P}>0,05)$ antara penambahan jamur tiram $20 \%$ dengan $30 \%$. Pada uji lanjut kadar abu terdapat perbedaan nyata $(\mathrm{P}<0,05)$ antar perlakuan. Kadar lemak terdapat perbedaan nyata $(\mathrm{P}<0,05)$ antar perlakuan, kecuali tidak berbeda nyata $(\mathrm{P}>0,05)$ antara penambahan jamur tiram $20 \%$ dengan $30 \%$. Pada uji lanjut kadar serat terdapat perbedaan nyata $(\mathrm{P}<0,05)$ antar perlakuan penambahan jamur tiram $10 \%$, kecuali tidak berbeda nyata $(\mathrm{P}>0,05)$ antara penambahan jamur tiram $20 \%$ dengan 30\%. Pada uji lanjut kadar protein terdapat perbedaan nyata $(\mathrm{P}<0,05)$ antar perlakuan, kecuali tidak berbeda nyata $(\mathrm{P}>0,05)$ antara penambahan jamur tiram $20 \%$ dengan $30 \%$.

Kadar air dapat mempengaruhi penampakan, tekstur, citarasa, penentu kesegaran dan daya simpan bahan pangan. Tingginya kadar air mengakibatkan mudahnya bakteri, kapang, dan khamir untuk berkembang biak, sehingga akan terjadi perubahan pada bahan pangan (Winarno, 2008). Peran air dalam pembuatan bakso yaitu sebagai bahan pelarut dari beberapa komponen tambahan dan bahan pereaksi (Purnomo, 2005), meningkatkan keempukan dan jus daging, pengganti sebagian air yang hilang selama proses pembuatan, pelarut protein yang mudah larut dalam air, pembentuk larutan garam yang diperlukan untuk melarutkan protein larut garam, sebagai fase kontinu dari emulsi daging, penjaga temperatur produk serta mempermudah penetrasi bahan-bahan curing (Soeparno, 2009). Kadar air bakso bervariasi dan ditentukan oleh kadar air daging ayam dan jamur tiram sebagai bahan utama bakso serta air es atau es batu sebagai bahan pelengkap. Penambahan air es dalam pembuatan bakso sebanyak 10-15\% dari berat daging (Winarno, 2008), dapat juga ditambahkan sebanyak 50 ml (Aziza, 2015). Hasil penelitian menggambarkan bahwa penambahan jamur tiram menyebabkan kandungan kadar air bakso cenderung meningkat karena penambahan kadar air bakso tidak sepenuhnya berasal dari jamur tiram, melainkan karena dalam pembuatan bakso tersebut diberi potongan es batu yang berbentuk butiran-butiran es sehingga secara langsung berpengaruh terhadap kandungan kadar air bakso. Syarat mutu bakso daging kombinasi adalah kadar air maksimal 70\% (BSN, 2014). Kadar air pada tabel 3 mencerminkan bahwa kadar air bakso yang ditambahkan jamur tiram lebih tinggi dari SNI, yang disebabkan karena persentase penambahan jamur tiram segar mengandung air sebesar 90,97\% dan daging ayam segar mengandung air mencapai 65,95\% (Suradi, 2006), sehingga menggambarkan bahwa semakin banyak persentase penambahan jamur tiram, maka kadar air bakso semakin meningkat dan bahan keringnya berkurang.

Jumlah mineral (abu) dalam makanan mencerminkan jumlah bahan organik yang terkandung dalam bahan makanan dan menggambarkan banyaknya mineral yang tidak 
terbakar menjadi zat yang dapat menguap. Kadar abu menggambarkan baik atau tidaknya suatu pengolahan yang dilakukan, dapat mengetahui keaslian bahan baku yang digunakan, dan penentu nilai gizi bakso. Syarat mutu kandungan abu pada bakso daging kombinasi maksimal 3\% (BSN, 2014). Kadar abu pada tabel 3 menunjukkan bahwa penambahan jamur tiram hingga $30 \%$ pada adonan bakso ayam broiler menghasilkan kadar abu sebesar

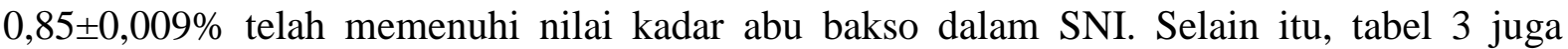
menggambarkan bahwa semakin banyak jumlah jamur tiram yang ditambahkan, maka kadar abu bakso semakin meningkat yang disebabkan karena jamur tiram kaya mineral diantaranya $314 \mathrm{mg}$ kalsium, 3,79 $\mathrm{mg}$ kalium, 717mg fosfor, dan 3,4-18,2 $\mathrm{mg}$ zat besi (Dirjen Hortikultura, 2006).

Lemak dapat menentukan aroma dan rasa serta mempengaruhi palatabilitas daging dan berperan dalam membentuk emulsi daging serta memberikan keempukan dan kebasahan pada bakso dan jika lemak cair keluar atau terpisah dari masa produk, maka akan terjadi penyimpangan sifat produk yang berakibat penurunan mutu (Soeparno, 2009). Lemak merupakan zat makanan yang penting untuk menjaga kesehatan dan sumber energi yang efektif yang sangat penting bagi tubuh. Tabel 3 menunjukkan bahwa penambahan jamur tiram menyebabkan kadar lemak bakso menurun dan nilainya lebih rendah dari kontrol, sehingga bakso ayam broiler dengan penambahan jamur tiram hingga 30\% menghasilkan kadar lemak lebih rendah dari SNI bakso daging kombinasi sebesar maksimal 10\% (BSN, 2014) yang menggambarkan bahwa masih aman untuk dikonsumsi. Hal tersebut disebabkan karena jamur tiram rendah lemak yaitu sebesar 1,7-2,2\% (Sumarmi, 2006). Semakin tinggi penambahan jamur tiram, maka semakin rendah pula kadar lemaknya, hal ini dikarenakan kadar air yang tinggi di dalam jamur akan menyebabkan kadar lemak menurun. Kadar air yang tinggi dalam bahan menyebabkan lemak sulit diekstraksi dengan pelarut non polar (ether) karena bahan pelarut sukar masuk ke dalam jaringan basah dan menyebabkan bahan pelarut menjadi jenuh dengan air sehingga kurang efisiensi untuk ekstraksi. Selain itu, jamur tiram mengandung lemak nabati terdiri dari fitosterol dan lebih banyak mengandung asam lemak tak jenuh sehingga umumnya berbentuk cair. Asam lemak jenuh bersifat lebih stabil (tidak mudah bereaksi) daripada asam lemak tak jenuh. Ikatan ganda pada asam lemak tak jenuh mudah bereaksi dengan oksigen/ mudah teroksidasi (Suradi, 2006).

Serat dalam bahan makanan (dietary fiber) sangat baik dan erat kaitannya dengan kesehatan konsumen. Dalam pendekatan epidemiologi yaitu hubungan konsumsi serat dan penyakit kolon tergolong rendah pada masyarakat di Benua Asia, karena umumnya masyarakat benua Asia mengkonsumsi lebih banyak serat dalam makanan sehingga menyebabkan rendahnya tingkat pengidap berbagai penyakit seperti diverticulitis, kanker kolon, atherosklerosis, coronary heart disease, diabetes mellitus dan appendicitis. Kecukupan asupan serat kini dianjurkan semakin tinggi, mengingat banyak manfaat yang menguntungkan untuk kesehatan tubuh, adequate intake (AI) untuk serat makanan sebagai acuan untuk menjaga kesehatan saluran pencernaan dan kesehatan lainnya kini telah dikeluarkan oleh Badan Kesehatan Internasional. Tabel 3 menunjukkan bahwa penambahan jamur tiram pada bakso ayam broiler menunjukkan kadar serat pada bakso P1 (10\% jamur 
tiram) mengandung serat tertinggi sebesar 2,53\%, sehingga cukup membantu memenuhi pemenuhan serat dalam bahan pangan.

Protein merupakan zat makanan yang sangat penting bagi tubuh, fungsinya sebagai bahan bakar dalam tubuh, zat pembangun dan pengatur, dengan fungsi utama untuk membentuk jaringan baru dan mempertahankan jaringan yang telah ada. Protein dalam bahan pangan pada umumnya, menentukan mutu dari suatu produk terutama yang berasal dari daging (Winarno, 2008). Penyuplai protein terbanyak dalam produk bakso adalah daging, oleh karena itu kandungan protein bakso berhubungan erat dengan jenis dan jumlah daging yang digunakan sebagai bahan baku utama. Kadar protein dipengaruhi oleh pemanasan pada saat proses pembuatan bakso. Kandungan protein daging ayam sebesar 18,2 gram per 100 gram (Suradi, 2006), sedangkan jamur tiram yang ditambahkan memiliki kadar protein yang lebih rendah daripada protein daging ayam, sehingga dapat menurunkan kadar protein dalam bakso. Syarat mutu protein bakso daging kombinasi minimal 8,0\% (BSN, 2014). Tabel 3 menunjukkan bahwa pada penambahan jamur tiram 10\% mengandung protein tertinggi sebesar 8,52 $\pm 0,014 \%$ telah memenuhi SNI. Penurunan kadar protein bakso pada P2 (20\% jamur tiram) dan P3 (30\% jamur tiram) dengan penambahan jamur tiram dapat disebabkan oleh banyaknya protein berbentuk globular. Protein jamur tiram putih adalah protein globular sama dengan protein dalam daging yang berbentuk bola, dapat larut dalam larutan garam dan larutan asam encer serta mudah terdenaturasi oleh pengaruh suhu, konsentrasi garam, pelarut asam dan basa (Winarno, 2008). Kesamaan jenis protein dalam jamur tiram dan daging ayam mempunyai persamaan ciri yang mudah terdenaturasi oleh pemanasan, larut dalam larutan garam dan larutan asam encer.

Berdasarkan hasil analisa komposisi kimia, penambahan jamur tiram pada bakso ayam broiler menghasilkan bakso terbaik yaitu penambahan jamur tiram 10\% (P1) dengan nilai kadar air terendah 71,3 $\pm 0,07 \%$ (mendekati SNI), kadar abu terendah 0,29 $\pm 0,002 \%$ (memenuhi SNI), kadar lemak tertinggi 0,22 $\pm 0,003 \%$ (memenuhi SNI), kadar serat tertinggi yaitu $2,53 \pm 0,003 \%$ dan protein tertinggi yaitu $8,52 \pm 0,014 \%$ (memenuhi SNI). Selain itu, jamur tiram (Pleurotus ostreatus) menjadi bahan pangan alternatif untuk pemenuhan nutrisi yang relatif murah mengandung serat, protein/asam amino, karbohidrat, mineral, lemak, dapat dikonsumsi anak-anak ataupun orang dewasa, lezat dengan berkhasiat obat, serta dapat sebagai immunomodulator (peningkat sistem kekebalan tubuh) dengan adanya senyawa aktif yaitu beta-glukan (Widyastuti, 2013) sehingga mengindikasikan bahwa penambahan jamur tiram dalam bakso ayam broiler dapat direkomendasikan menjadi terapi gizi di tengah masa pandemi Covid-19.

\section{Nilai Organoleptik Bakso Ayam Broiler Dengan Penambahan Jamur Tiram}

Analisis sensori sangat penting pada produk pangan, selain nilai gizi pangan yang tinggi serta kehigienisannya. Jika rasa dari suatu produk pangan tidak enak, maka nilai gizi pangan tidak dapat termanfaatkan karena tidak ada yang tertarik untuk mengkonsumsi. Begitu pula dengan wewangian, semakin langka dan disukai keharumannya, maka harganya akan semakin mahal. Selera konsumen sangat menentukan dalam penerimaan dan penilaian suatu produk. Kualitas sensori yang tinggi (Setyaningsih, dkk., 2010) ditentukan oleh respon 
secara positif oleh indra manusia, sehingga menghasilkan kesan subjektif yang menyenangkan dan memuaskan harapan konsumen. Hasil uji organoleptik bakso ayam broiler dengan penambahan jamur tiram terdapat pada tabel 4 .

Tabel 4. Rataan Nilai Organoleptik Bakso Ayam Broiler Dengan Penambahan Jamur Tiram

\begin{tabular}{|c|c|c|c|c|c|}
\hline \multirow{2}{*}{$\begin{array}{c}\text { Parameter Nilai } \\
\text { Organoleptik }\end{array}$} & \multicolumn{4}{|c|}{ Persentase Penambahan Jamur Tiram } & \multirow[t]{2}{*}{$\mathrm{P}$} \\
\hline & $\begin{array}{c}\mathrm{K} \text { (kontrol) } \\
(0 \%)\end{array}$ & P1 (10\%) & P2 (20\%) & P3 (30\%) & \\
\hline Warna & $3,27 \pm 1,11^{\mathbf{a}}$ & $3,40 \pm 0,77^{\mathbf{b}}$ & $3,67 \pm 0,76^{\mathbf{c}}$ & $3,87 \pm 0,68^{\mathbf{c}}$ & S \\
\hline Rasa & $3,00 \pm 1,23^{\mathbf{a}}$ & $3,40 \pm 1,13^{\mathbf{b}}$ & $3,57 \pm 0,97^{\mathrm{c}}$ & $3,83 \pm 0,99^{\mathbf{c}}$ & $\mathrm{S}$ \\
\hline Aroma & $3,07 \pm 0,94$ & $3,40 \pm 1,00$ & $3,40 \pm 0,97$ & $3,40 \pm 0,89$ & NS \\
\hline Tekstur & $3,13 \pm 1,33$ & $3,27 \pm 1,26$ & $3,43 \pm 0,97$ & $3,73 \pm 1,08$ & NS \\
\hline Penerimaan & $3,12 \pm 0,11^{\mathbf{a}}$ & $3,37 \pm 0,07^{\mathbf{a}}$ & $3,52 \pm 0,13^{\mathbf{b}}$ & $3,71 \pm 0,21^{\mathbf{b}}$ & $\mathrm{S}$ \\
\hline
\end{tabular}

Sumber: Data Primer Diolah (2020).

Keterangan :

S: Signifikan NS: Tidak signifikan

Superskrip yang berbeda pada baris yang sama menunjukkan perbedaan yang nyata $(\mathrm{P}<0,05)$

Nilai 1 : Tidak suka, 2 : Kurang suka, 3 : Cukup suka, 4 : Suka, 5 : Sangat suka

Jangkauan nilai: $\quad$ Tidak suka $: 0,0-1,0$

Kurang suka $: 1,1-2,0$

Cukup suka $: 2,1-3,0$

Suka $\quad: 3,1-4,0$

Sangat suka $: 4,1-5,0$

Tabel 4 menggambarkan bahwa rataan nilai organoleptik penambahan jamur tiram dalam bakso ayam broiler bervariasi antar perlakuan. Rataan tingkat kesukaan warna bakso

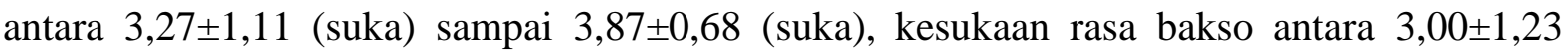

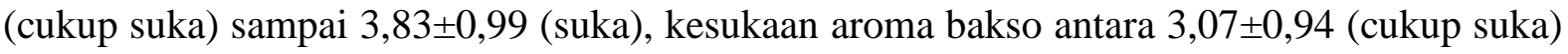

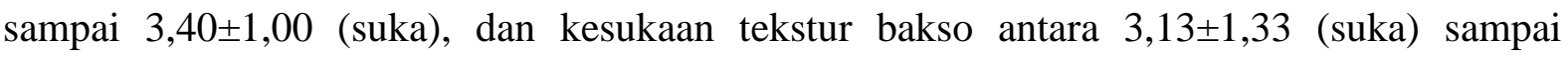

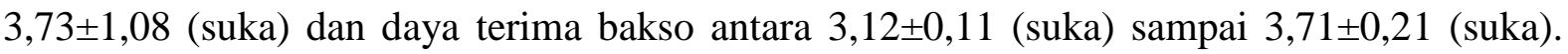
Berdasarkan analisa statistik, penambahan jamur tiram pada bakso ayam broiler berpengaruh nyata $(\mathrm{P}>0,05)$ terhadap nilai organoleptik meliputi warna dan rasa serta daya terima bakso, tetapi tidak berpengaruh nyata $(\mathrm{P}<0,05)$ terhadap aroma dan tekstur bakso. Warna adalah parameter sensorik yang dapat dilihat langsung oleh panelis dan menjadi pertimbangan pertama sebelum rasa dan gizi bakso.

Warna bakso hasil penelitian memberikan warna normal yang lebih cerah dan lebih putih kekuningan. Warna normal bakso yang dihasilkan telah sesuai SNI, dimana syarat mutu warna bakso daging kombinasi yaitu normal (BSN, 2014). Tingkat kesukaan warna bakso dengan penambahan jamur tiram (tabel 4) menunjukkan bahwa kesukaan warna bakso berada pada taraf suka. Penambahan jamur tiram hingga 30\% menghasilkan nilai kesukaan warna tertinggi, diduga disebabkan oleh jumlah komposisi jamur tiram yang digunakan lebih banyak, sehingga mempengaruhi intensitas warna dari produk bakso. Warna bakso yang dihasilkan dalam penelitian ini lebih cerah karena selama proses perebusan, daging ayam dan jamur tiram mengalami proses pemucatan karena proses pemanfaatan panas seperti pemasakan dapat mengakibatkan perubahan pada penampakan cita rasa, bau dan tekstur. 
Faktor yang mempengaruhi kecepatan pengurangan kadar air selama perebusan adalah luas permukaan, konsentrasi zat terlarut dalam air panas dan pengadukan. Selain itu, hasil penelitian Sutikarini, dkk. (2015) menyatakan bahwa tingkat kesukaan panelis terhadap warna tertinggi terdapat pada pengolahan jamur tiram dengan di rebus.

Rasa adalah faktor kedua yang mempengaruhi citarasa makanan setelah penampilan makanan dan tanggapan atas adanya rangsangan kimiawi yang sampai di indra pengecap lidah. Rasa adalah faktor penting terhadap penerimaan bakso, meskipun parameter lain nilainya baik, jika rasa bakso tidak enak atau tidak disukai maka bakso akan ditolak. Bakso hasil penelitian memberikan rasa lezat, enak dan rasa dominan daging dengan bumbu yang menonjol. Tabel 4 menunjukkan bahwa penambahan jamur tiram hingga 30\% pada bakso ayam broiler memberikan peningkatan kesukaan terhadap rasa bakso yang berada pada taraf cukup suka sampai suka serta telah memenuhi SNI, karena rasa bakso yang dikehendaki adalah lezat, enak, rasa daging dominan, rasa bumbu cukup menonjol tetapi tidak berlebihan dan tidak terdapat rasa asing yang mengganggu (BSN, 2014). Hal tersebut disebabkan karena jamur tiram menimbulkan rasa lezat karena kandungan gizi terutama protein yang tinggi (Dirjen Hortikultura, 2006) dan sangat ideal sebagai sumber makanan karena mengandung semua asam amino esensial yang diperlukan tubuh dapat seperti halnya daging, ikan ataupun sayuran dan lebih sehat untuk dikonsumsi (Widyastuti, 2013). Rasa yang dimiliki jamur tiram mengakibatkan rasa dari bakso pada penelitian ini menjadi lebih enak dan meningkatkan rangsangan kesukaan oleh panelis, sehingga tingkat kesukaan panelis menjadi meningkat dari cukup suka menjadi suka, karena cita rasa bahan pangan sebenarnya terdiri dari tiga komponen pokok yaitu bau, rasa, dan rangsangan mulut. Rasa melibatkan panca indera lidah sebagai pengecap rasa pahit, manis, asin dan asam, sedangkan mulut menimbulkan sensasi perasaan pada seseorang setelah menelan suatu bahan makanan (Winarno, 2008).

Aroma bahan makanan menentukan kelezatan suatu makanan. Uji aroma dalam industri makanan sangat penting dilakukan karena dengan cepat dapat memberikan hasil penilaian produk disukai atau tidak disukai. Aroma adalah bau yang ditimbulkan oleh rangsangan kimia yang tercium otleh syaraf-syaraf olfaktori yang melibatkan organ pencicipan dan penciuman yang berada dalam rongga hidung. Aroma bakso yang disukai adalah aroma daging rebus yang kuat (Hermanianto dan Andayani, 2002). Bakso hasil penelitian beraroma khas daging ayam, sehingga memenuhi syarat mutu bakso daging kombinasi yaitu aroma khas normal daging (BSN, 2014). Rasa bakso dipengaruhi oleh formulasi bumbu, bahan pengisi dan kondisi daging yang digunakan (Soeparno, 2009). Tabel 4 menunjukkan penambahan jamur tiram pada bakso ayam broiler tidak mempengaruhi aroma bakso. Nilai kesukaan aroma bakso berada pada taraf suka dan menggambarkan bahwa penambahan jamur tiram hingga 30\% dapat diterima konsumen.

Tekstur merupakan salah satu parameter dalam pengujian organoleptik yang dapat dirasakan melalui kulit atau indera peraba. Tekstur pada daging yang disuwir, umumnya akan berbentuk seperti serat-serat halus yang diperoleh dari penginderaan yang dihubungkan dengan rabaan atau sentuhan dan kehalusan suatu irisan saat disentuh dengan jari oleh panelis. Kesukaan panelis terhadap tekstur bakso dipengaruhi oleh kesan keempukan yaitu kemudahan awal penetrasi gigi dengan daging dikunyah menjadi potongan-potongan yang 
lebih kecil dan jumlah residu setelah pengunyahan. Hasil penelitian menunjukkan bahwa penambahan jamur tiram pada adonan bakso ayam broiler tidak berpengaruh sangat nyata $(\mathrm{P}<0,01)$ terhadap kesukaan tekstur bakso. Perlakuan jamur tiram 30\% memiliki nilai tertinggi dan teksturnya kenyal. Hasil tersebut menggambarkan bahwa penambahan jamur tiram hingga 30\% dapat diterima konsumen dan memenuhi syarat mutu tekstur bakso daging kombinasi yaitu kenyal (BSN, 2014). Nilai kesukaan tekstur bakso (tabel 4) yang berada pada taraf suka disebabkan karena jamur tiram memiliki kandungan karbohidrat yang tidak tercerna yang menyebabkan tekstur bakso menjadi lebih kompak dan kenyal. Jamur tiram memiliki tekstur kenyal dan lembut sehingga mirip tekstur daging ayam dan warnanya putih kekuningan dan saat proses perebusan bakso, jamur tiram menjadi lunak dan proteinnya terdenaturasi serta beberapa senyawa kimia ikut larut dalam air rebusan sehingga tingkat kesukaan panelis tertinggi pada pengolahan jamur tiram dengan proses perebusan (Sutikarini, dkk., 2015).

Penilaian daya terima bakso menjadi penentu bahwa bakso dapat diterima dan dikonsumsi panelis. Hasil penelitian (tabel 4) menunjukkan bahwa bakso ayam broiler dengan penambahan jamur tiram sampai $30 \%$ berada pada taraf suka yang menggambarkan bahwa tingkat kesukaan pada bakso secara keseluruhan bersifat dapat diterima dan dapat dikonsumsi, karena panelis masih dapat menerima bakso baik dari segi warna, rasa, aroma dan tekstur. Tingkat penerimaan bakso dipengaruhi oleh kesukaan warna dan rasa karena terjadi peningkatan kesukaan terhadap warna dan rasa maupun tekstur bakso. Tingkat penerimaan bakso pada semua perlakuan penambahan jamur tiram secara keseluruhan memiliki daya terima dan disukai panelis.

\section{KESIMPULAN}

Penambahan jamur tiram dalam adonan bakso ayam broiler memberikan pengaruh sangat nyata $(\mathrm{P}>0,01)$ terhadap nilai komposisi kimia yaitu kadar air, abu, lemak, serat dan protein dan berpengaruh nyata $(\mathrm{P}>0,05)$ terhadap nilai organoleptik yaitu kesukaan warna, rasa dan daya terima bakso, tetapi tidak berpengaruh nyata $(\mathrm{P}<0,05)$ terhadap kesukaan aroma dan tekstur bakso. Formulasi penambahan jamur tiram pada bakso ayam broiler berdasarkan nilai komposisi kimia terdapat pada penambahan jamur tiram 10\% mengandung protein tertinggi sebesar $8,51 \pm 0,014 \%$, jika dibandingkan penambahan jamur tiram $0 \%, 20 \%$ dan 30\% dan telah memenuhi SNI bakso daging kombinasi dan dapat direkomendasikan menjadi terapi gizi di tengah masa pandemi Covid-19. Berdasarkan nilai organoleptik, formulasi bakso ayam broiler dengan penambahan jamur tiram sebanyak $30 \%$ dapat memberikan nilai organoleptik (warna, rasa dan daya terima) lebih tinggi jika dibandingkan dengan penambahan jamur tiram $0 \%, 10 \%$ dan $20 \%$.

\section{Ucapan Terima Kasih}

Peneliti mengucapkan terima kasih kepada Peneliti mengucapkan terima kasih kepada Kementerian Pendidikan dan Kebudayaan atas dana yang diberikan melalui penelitian skim Penelitian Dosen Pemula Perguruan Tinggi tahun 2019 dan tahun pelaksanaan 2020 dengan nomor kontrak B/87/E3/RA.00/2020 dan Surat Perjanjian Penugasan Program Penelitian Nomor: 008/SP2H/LT/PPM/V/2020, tanggal 30 Mei 2020. 


\section{DAFTAR PUSTAKA}

Aziza, T., Dian R. Affandi, Godras J. Manuhara. 2015. Bakso Ikan Tongkol Dengan Filler Tepung Gembili Sebagai Fortifikan Inulin. Jurnal Teknologi Pangan. 8(3): 77-83.

Badan Pusat Statistik. 2018. Statistik Konsumsi Pangan. Rata-rata Konsumsi Jamur PerKapita. Pusat Data dan Sistem Informasi Pertanian. http://www.epertanian.go.id diakses 10 September 2020.

Badan Standarisasi Nasional. 2014. Syarat Nasional Indonesia (SNI) 3818:2014 Tentang Syarat Mutu Bakso Daging.

Dirjen Hotikultura. 2006. Jamur Tiram. Deptan RI.

FAO. 2011. Animal Production and Health Manual No. 14. FAO, Rome, Italy. Food and Agriculture Organization of the United Nations.

Hermanianto dan Andayani, 2002. Studi Perilaku Konsumen dan Identifikasi Parameter Bakso Sapi Berdasarkan Preferensi Konsumen Di Wilayah DKI Jakarta. Jurnal Teknologi dan Industri Pangan. 13(1):1-10.

Kusharto, Clara M. 2006. Serat Makanan Dan Peranannya Bagi Kesehatan (Dietary Fiber and Its Role for Health). Jurnal Gizi dan Pangan, November 2006 1(2): 45-54.

Munassir, B., Nurhaeda, dan Irmayani. 2018. Kandungan Kadar Air Dan Protein Pada Bakso Ayam Broiler Dengan Putih Telur Sebagai Bahan Pengenyal Pada Konsentrasi Yang Berbeda. Jurnal Bionature. 19(2): 90-94.

Purnomo. 2005. Fungsi Daging Ayam Dalam Pembuatan Bakso. Universitas Muhammadiyah. Semarang.

Purnomo. H. 1997. Pengaruh Substitusi Tepung Dan Tepung Kedelai Terhadap Terhadap Terhadap Kualitas Bakso. Agrivita. 20 (3):138-141. Jakarta.

Setjen Pertanian RI. 2015. Statistik Konsumsi Pangan 205. Page 65. Center for Agriculture

Data And Information System. https://epublikasi.setjen.pertanian.go.id diakses 10 September 2020.

Setyaningsih, D., Anton A. Maya P.S. 2010. Analisis Sensori: Untuk Industri Pangan Dan Agro. Bogor : IPB Press.

Soeparno. 2009. Ilmu Dan Teknologi Daging. Gajah Mada Universitas Press. Yogyakarta.

Sumarmi. 2006. Botani dan Tinjauan Gizi Jamur Tiram Putih. Jurnal Inovasi Pertanian 4(2): 124-130.

Suradi, K. 2006. Perubahan Sifat Fisik Daging Ayam Broiler Post Mortem Selama Penyimpanan Temperatur Ruang (Change of Physical Characteristics of Broiler Chicken Meat Post Mortem During Room Temperature Storage). Jurnal Ilmu Ternak. 6(1): 23-27.

Suradi, K. 2007. Tingkat Kesukaan Bakso dari Berbagai Jenis Daging Melalui Beberapa Pendekatan Statistik (The Hedonic Scaling of Meatball from Various kind of Meat on Several Statistic Approached). Jurnal Ilmu Ternak. 7(1): 52-57.

Sutikarini, S. Anggrahini, dan E. Harmayani. 2015. Perubahan Komposisi Kimia dan Sifat Organoleptik Jamur Tiram Putih (Pleurotus ostreatus) Selama Pengolahan. Jurnal Ilmiah Agrosains Tropis. 8(6): 261-271. 
Thomy, Zairin. 2004. Industri Budidaya Jamur Konsumsi di Indonesia. Prosiding Pra Workshop Pengembangan Produk dan Industri Jamur Pangan Indonesia BPP Teknologi. Jakarta, 1-2 Agustus 2005. Tim BPPT.

Tjokrokusumo, Donowati. 2008. Jamur Tiram (Pleurotus ostreatus) Untuk Meningkatkan Ketahanan Pangan Dan Rehabilitasi Lingkungan. Jurnal Rekayasa Lingkungan. 4(1): 53-62.

Widyastuti, Netty. 2013. Pengolahan Jamur Tiram (Pleurotus Ostreatus) Sebagai Alternatif Pemenuhan Nutrisi. Jurnal Sains dan Teknologi Indonesia. 15(3): 4-9.

Winarno, F. G. 2008. Kimia Pangan dan Gizi. Gramedia Pustaka Utama. Jakarta. 